\title{
PENGARUH SISTEM PENGUKURAN KINERJA DAN KEJELASAN PERAN TERHADAP KINERJA KARYAWAN
}

\author{
Siti Khoirina \\ Perguruan Tinggi Mitra Lampung (UMITRA) \\ Email: puputkhoirina@yahoo.co.id
}

\begin{abstract}
This study aims to examine the effect of performance measurement systems and role clarity on the performance of employees, especially employees of banking in Lampung, Palembang, Jambi and Bengkulu. This study is expected to benefit over the role of performance measurement and clarity.

Based on the results of the test by using partial least squares (PLS) SPK known that directly influence the performance of employees and indirectly through role clarity. In addition to seeing how the indirect effect of role clarity on the relationship between the SPK and the performance of employees, the authors conducted a track test. Based on the test track using Sobel's test found that SPK relations and employee performance is influenced by factors mediating role clarity.
\end{abstract}

Keywords: Performance measument system, role clarity, Performance of employees

\section{LATAR BELAKANG}

Pada awalnya pengukuran kinerja organisasi perusahaan lebih ditekankan pada pengukuran kinerja keuangan namun seiring perkembangan dan perubahan-perubahan yang semakin pesat pengukuran kinerja non-keuangan mulai diterapkan. Menurut Kaplan dan Norton (1996) pengukuran kinerja non-keuangan bisa digunakan untuk melengkapi pengukuran kinerja keuangan jangka pendek sebagai indikator kinerja jangka panjang. Sistem pengukuran kinerja (SPK) menyediakan informasi yang relevan dengan pengambilan keputusan. Informasi yang relevan diperoleh dari alat ukur kinerja yang mencakup aspek keuangan dan non keuangan.

Chenhall (2005) menemukan bahwa integritas adalah atribut penting dalam SPK, kelengkapan karakteristik informasi SPK yaitu sejauh mana SPK menyediakan informasi kinerja bagi para karyawan. Kelengkapan itu berasal dari penyediaan ukuran kinerja yang menggambarkan bagian-bagian penting dari pekerjaan karyawan di perusahaan jasa. Kejelasan peran dapat dioperasionalkan setidaknya dengan dua cara, pertama, bersifat objektif dapat diartikan sebagai ada atau tidaknya kejelasan informasi peran baik tipe 
pengukuran kejelasan peran informasi tersebut atau larangan atas ditindakan yang tidak boleh dilakukan. Kedua, bersifat subyektif atas keinginan seberapa besar informasi peran yang ingin diperoleh oleh seseorang, (Lyons, 1971, p. 100).

Penelitian ini bertujuan mengkaji pengaruh sistem pengukuran kinerja dan kejelasan peran terhadap kinerja karyawan khususnya karyawan perbankan di Lampung, Palembang, Jambi dan Bengkulu. Hal ini dilakukan karena karakteristik perusahaan jasa sangat dominan dalam perekonomian hampir di seluruh dunia (Goodale et al. 2008; Machuca et al. 2007; Spohrer and Maglio 2008; Beyers 2010; Ettlie and Rosenthal 2012). Akan tetapi studi di sektor tersebut, khususnya bidang akuntansi manajemen sangat terbatas (Chenhall 2005; Collier and Gregory 1995a, 1995b; Shields 1997; Kihn 2010). Chenhall (2003) mengatakan bahwa adanya kebutuhan yang lebih penting untuk penelitian di perusahaan jasa. karena sektor ini menjadi bagian penting dalam hampir setiap kegiatan ekonomi. Dan berdasarkan tulisan terkini, Kihn, (2010p, 484) yang menjelaskan bahwa banyak kesenjangan dan kurangnya perhatian atas penelitian di sektor jasa untuk menambah literatur dalam penelitian di akuntansi manajemen. Berdasarkan penelitian Chenhall (2005) "Sektor jasa keuangan merupakan komponen penting dalam ekonomi di dunia. Penggunaan sampel dari sektor jasa keuangan akan memberikan ukuran yang berbeda untuk melihat hubungan antara sistem pengukuran kinerja dan kinerja karyawan. Studi ini diharapkan dapat memberikan manfaat atas pengukuran kinerja dan kejelasan peran.

\section{TELAAH TEORI DAN PENGEMBANGAN HIPOTHESIS}

\subsection{Telaah Teori}

\section{Teori Motivasi}

Dalam melakukan pekerjaannya seorang karyawan terdorong oleh kebutuhan dan keinginan yang harus dicapai dalam hasil kerjanya, diantaranya adalah pemenuhan kebutuhan hidup sehari-hari dan keinginan untuk melakukan pekerjaan dengan baik. Dengan kata lain dapat diartikan bahwa dorongan, kebutuhan dan keinginan seseorang untuk melakukan aktifitas kesehariannya disebut motivasi. Motivasi sebagai suatu proses dan usaha dalam menentukan arah, intensitas dan ketekunan dalam diri seseorang untuk mencapai tujuan( Robbins, 2006).

Mc Clelland (1967), menyatakan bahwa ada tiga hal penting yang menjadi kebutuhan manusia, yaitu: Need for achievement (kebutuhan akan prestasi), Need for afiliation 
(kebutuhan akan hubungan sosial/hampir sama dengan soscialneed-nya Maslow), Need for Power (dorongan untuk mengatur)

\section{Sistem Pengukuran Kinerja}

Bititci (1994) mengatakan bahwa SPK dan produktivitas mendapatkan perhatian yang sangat signifikan baik bagi akademik maupun perusahaan. Banyak kemajuan yang telah dilakukan dalam pengembangan SPK yang bertujuan untuk menyeimbangkan pengukuran yang berorientasi pada aspek keuangan. Jackson dan Schuler (1985), dan Tubre dan Collins (2000) menemukan bukti bahwa pemahaman yang tinggi terhadap tujuan suatu pekerjaan, dapat memberikan informasi yang relevan terhadap pekerjaan dan motivasi untuk meningkatkan kinerja suatu pekerjaan.

\section{Kejelasan Peran}

Sawyer (1992) mendefinisikan kejelasan peran dengan dua aspek yaitu: Goal Clarity dan Process Clarity. Goal Clarity adalah seberapa besar hasil, tujuan dan sasaran suatu pekerjaan dinyatakan secara jelas. Sedangkan Process Clarity adalah seberapa besar individu tahu mengenai bagaimana untuk melaksanakan pekerjaannya. Kejelasan tujuan (Goal Clarity) mengacu pada tujuan akhir dimana tujuan pekerjaan tersebut dijelaskan dengan teliti dan didefinisikan dengan baik, sedangkan Kejelasan proses (Process Clarity) adalah keyakinan individu terhadap hasil kinerjanya. Kejelasan peran merujuk kepada persepsi seorang individu tentang harapan dan perilaku yang berkaitan dengan peranannya (Binnewies et al. 2008 ; Kahn et al, 1964 dalam Hall, 2008).

\section{Kinerja Karyawan}

Gomes (1995) mengatakan kinerja suatu pekerjaan adalah catatan hasil atau keluaran (outcomes) yang dihasilkan dari suatu fungsi pekerjaan tertentu atau kegiatan tertentu dalam suatu periode waktu tertentu. Kinerja merupakan indikator dalam menentukan bagaimana usaha untuk mencapai tingkat produktivitas yang tinggi dalam suatu organisasi atau instansi.

\subsection{Hipotesis}

Sistem pengukuran kinerja diharapkan dapat meningkatkan kejelasan peran melalui informasi yang dapat meningkatkan motivasi karyawan untuk melaksanakan tugas yang telah ditetapkan yang pada akhirnya informasi mengenai kejelasan peran akan meningkatkan kinerja karyawan. 


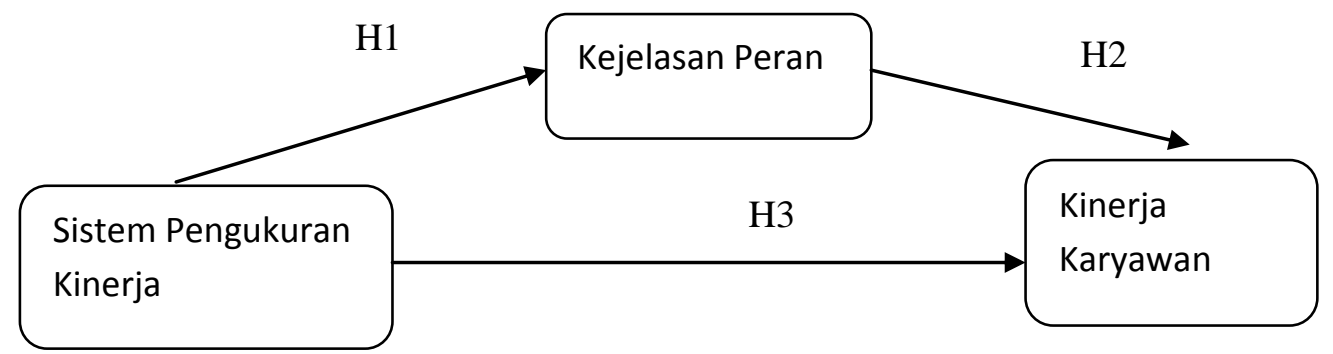

Gambar 1.1:

\section{Research framework hubungan antara SPK, kejelasan peran, terhadap kinerja karyawan}

\section{Pengaruh sistem pengukuran kinerja terhadap kejelasan peran.}

Sistem pengukuran kinerja dapat memberikan gambaran mengenai tujuan dan sasaran kerja bagi setiap individu, nilai dan jenis peluang yang dapat dimanfaatkan oleh individu dalam menyelesaikan pekerjaan. Hal ini dapat diraih dengan memfokuskan secara sistematis pada informasi yang bermanfaat dan mengabaikan informasi yang tidak relevan. Informasi kinerja diharapkan dapat meningkatkan pemahaman karyawan akan pekerjaan mereka dan dapat meningkatkan kejelasan peran karyawan. Hipotesis yang dibangun atas penjelasan di atas adalah sebagai berikut:

\section{H1 : Sistem pengukuran kinerja berpengaruh positif terhadap kejelasan peran.}

\section{Pengaruh Kejelasan Peran terhadap Kinerja Karyawan.}

Kejelasan peran diharapkan dapat meningkatkan motivasi dan pada akhirnya dapat meningkatkan kinerja akan suatu pekerjaan (Jackson dan Schuler, 1985; Abramis, 1994; Tube dan Collins, 2000). Maka kejelasan peran berpengaruh pada kinerja karyawan karena kejelasan peran dapat memperkuat suatu kinerja. Dengan demikian dapat diajukan hipotesis sebagai berikut:

\section{H2 : Kejelasan Peran berpengaruh positif terhadap kinerja karyawan.}

\section{Pengaruh Sistem Pengukuran Kinerja terhadap Kinerja Karyawan.}

Sistem pengukuran kinerja dapat menjelaskan perilaku yang tepat dengan menyediakan informasi kinerja yang komprehensif yang dapat meningkatkan pemahaman seorang karyawan akan pemicu suatu kinerja, dampak dari suatu tindakan atas rantai nilai, dan hubungan antara bagian yang berbeda dalam operasional perusahaan. Lawler (1992) 
berargumen bahwa informasi tentang misi suatu organisasi dan kinerja dibutuhkan untuk individu yang mengetahui bagaimana harus bertindak. Hipotesis yang di ajukan adalah :

\section{H3: Sistem pengukuran kinerja berpengaruh positif terhadap kinerja karyawan.}

\section{METODE PENELITIAN}

\subsection{Sampel Penelitian}

Penelitian ini menggunakan metode survey atas perusahaan jasa khususnya perbankan yang terdapat di Lampung, Palembang, Jambi dan Bengkulu. Penulis menyebar 200 set quesioner dengan responden karyawan yang bekerja lebih dari tiga tahun. Studi pendahuluan dilakukan untuk melihat dan menguji keakurasian terjemahan bahasa Inggris ke dalam bahasa Indonesia. Hal ini penulis lakukan dengan menemui beberapa orang yang memiliki kemampuan bahasa Inggris yang baik, seperti guru bahasa Inggris, dosen dan staf pada balai bahasa Unila. Hasil terjemahan atas kuesioner tersebut di cocokkan satu sama lain untuk di susun menjadi kuesioner yang layak disebarkan. Studi pendahuluan ke dua dilakukan dengan menyebar kuesioner ke beberapa bank se Sumbagsel sebagai pilot study.

\subsection{Pengukuran Variabel}

\section{Sistem pengukuran kinerja komprehensif}

Kuesioner tentang sistem pengukuran kinerja (SPK) komprehensif menanyakan seberapa besar informasi tentang sistem pengukuran kinerja. Instrument ini dikembangkan oleh Hall (2008). Kuesioner ini untuk mengetahui seberapa besar SPK bersifat komprehensif. Diajukan sembilan pertanyaan menggunakan 7 point skala likert, 1 jika tidak sama sekali hingga nilai 7 jika sangat besar. Skala ini terdiri dari 9 item. Lima item terkait dengan sejauh mana SPK menyediakan berbagai informasi kinerja tentang bagian-bagian penting dari perusahaan jasa (Hall, 2008, p.150), empat item diambil dari Chenhall (2005), dan berhubungan dengan tingkat integrasi dengan langkah-langkah strategi. Pertanyaan tersebut menunjukkan bahwa kita tertarik pada sejauh mana SPK menyediakan informasi tentang operasi unit usaha. (Hall, 2008, p.150). 


\section{Kejelasan peran}

Instrumen variabel kejelasan peran yang dikembangkan oleh Sawyer (1992) terdiri dari 10 item pertanyaan yang berkaitan dengan tugas dan tanggung jawab karyawan dalam melaksanakan tugasnya. Dengan menggunakan skala likert dari nilai 1 jika tidak jelas hingga nilai 7 jika sangat jelas.

\section{Kinerja karyawan}

Kinerja adalah suatu prestasi yang di capai oleh seseorang dalam melaksanakan tugas atau pekerjaannya sesuai dengan standar kriteria yang diterapkan dalam pekerjaan itu. Sistem pengukuran kinerja diharapkan akan mempengaruhi hasil kerja karyawan. Instrumen ini dikembangkan oleh Burney dan Widener (2009). Responden ditanya seberapa besar pendapat mereka atas pertanyaan tersebut dengan menggunakan skala likert $1-7$.

\section{HASIL DAN PEMBAHASAN}

Smith and Langfield-Smith 2004, p. 59-60 bahwa keuntungan menggunakan SEM adalah memungkinkan berbagai hubungan antara variabel yang akan diakui dalam analisis. SEM menyediakan peneliti dengan kesempatan untuk mengadopsi pendekatan yang lebih holistik untuk membangun model, menjelaskan efek dari kesalahan pengukuran estimasi variabel laten adalah perbedaan utama antara SEM dan kedua analisis jalur dan analisis regresi berganda.Kemudian penulis memilih menggunakan PLS, dengan alasan karena PLS is prediction-oriented (Urbach and Ahlemann 2010), prediction -oriented (Urbach and Ahlemann 2010), Fornel (1982, p. 443) mengatakan, 'there are no distributional requirements' (Henseler, Ringle, \& Sinkovics, 2009, p. 288-289 ).

Baines \& Langfield - Smith (2003) menyatakan bahwa analisis data dengan menggunakan SEM harus melalui dua tahapan yaitu: pertama, pengukuran model, untuk menguji reliabilitas dan validitas (Camison \& Lopez, 2010; Hartmann \& Slapnicar, 2009; Hulland, 1999). Pengujian validitas menggunakan PLS dapat dilihat dari pengujian Validitas convergen dapat dihitung dengan melihat skor Average Variance Extracted (AVE). Henseler et al.(2009) mengatakan bahwa nilai validitas convergent sangat baik apabila skor AVE diatas 0,5. Dan Validitas discriminant, untuk melihat apakah item adalah unik dan tidak sama dengan konstruk lain dalam model (Hulland, 1999). Untuk menguji validitas diskriminan dapat dilakukan dengan dua metode yaitu metode Fornell-Larcker dilakukan dengan 
membandingkan square roots atas AVE dengan korelasi vertical laten dan metode Crossloading yang menyatakan bahwa semua item harus lebih besar dari konstruk lainnya (AlGahtani, Hubona, \& Wang, 2007). Kedua, Pengukuran Struktural model, diukur dengan ratarata $\mathrm{R}^{2}$ untuk variabel terikat dan pengujian koefisiensi jalur. Menurut Camison \& Lopez (2010) dan Falk \& Miller (1992) bahwa nilai $\mathrm{R}^{2}$ lebh dari 0.1 dapat diterima. Pengujian ini dilakukan menggunakan prosedur bootstrap dengan 500 penggantian (e.g. Hartmann \& Slapnicar, 2009)

\subsection{Statistik Deskriptif \\ Deskriptif Responden}

Responden dalam penelitian ini adalah para karyawan bank yang telah bekerja di perbankan lebih dari tiga tahun di Lampung, Palembang, Bengkulu dan Jambi. Karyawan yang menjadi sampel diberi kuesioner yang berisi kumpulan pertanyaan tentang profil responden yang terdiri dari jenis kelamin, usia, pendidikan terakhir, posisi, divisi kerja, lama bekerja dan tipe bank.

Data yang digunakan dalam penelitian ini adalah data primer yang diperoleh melalui kuisioner yang disebar kepada 200 karyawan kantor cabang bank yang ada di Sumbagsel meliputi Lampung, Palembang, Bengkulu dan Jambi. Atas 200 set, penulis menerima respon sebanyak $163(81,5 \%)$ kuesioner yang dikembalikan.

\section{Tabel 4.1}

Demografi responden

\begin{tabular}{|l|l|r|r|r|l|}
\hline & & $\mathrm{N}$ & Komulatif & $\%$ & $\begin{array}{l}\text { Komulatif } \\
(\%)\end{array}$ \\
\hline \multirow{2}{*}{ Jenis Kelamin } & Pria & 88 & 88 & 53.99 & 53.99 \\
& Wanita & 75 & 163 & 46.01 & 100 \\
\hline \multirow{5}{*}{ Usia } & $<30$ & 84 & 84 & 51.53 & 51.53 \\
& $31-40$ & 54 & 138 & 33.13 & 84.66 \\
& $41-50$ & 23 & 161 & 14.11 & 98.77 \\
& $>51$ & 2 & 163 & 1.23 & 100 \\
\hline \multirow{2}{*}{ Pendidikan } & SMA/Diploma & 28 & 28 & 17.18 & 17.18 \\
Terakhir & Sarjana(S1) & 111 & 139 & 68.10 & 85.28 \\
& S2/S3 & 24 & 163 & 14.72 & 100 \\
\hline \multirow{2}{*}{ Jabatan } & Manajer & 61 & 61 & 37.42 & 37.42 \\
& Non-Manajer & 102 & 163 & 62.58 & 100 \\
\hline \multirow{3}{*}{ Divisi Kerja } & Keuangan & 46 & 46 & 28.22 & 28.22 \\
& Umum & 28 & 74 & 17.18 & 45.40 \\
& SDM & 15 & 89 & 9.20 & 54.60 \\
\hline
\end{tabular}




\begin{tabular}{|l|l|r|l|r|l|}
\hline & Pemasaran & 35 & 124 & 21.47 & 76.07 \\
& Lain-lain & 39 & 163 & 23.93 & 100 \\
\hline \multirow{3}{*}{ Lama Bekerja } & $<5$ & 116 & 116 & 71.17 & 71.17 \\
& $6-10$ & 39 & 155 & 23.93 & 95.10 \\
& $>11$ & 8 & 163 & 4.91 & 100 \\
\hline \multirow{2}{*}{ Tipe Bank } & Konvensional & 101 & 101 & 61.96 & 61.96 \\
& Syariah & 62 & 163 & 38.04 & 100 \\
\hline
\end{tabular}

\section{Deskriptif Statistik}

Deskriptif statistik dalam penelitian ini terlihat pada tabel 4.2 sebagai berikut :

Tabel 4.2

Deskriptif Statistik

\begin{tabular}{|l|l|l|l|l|l|}
\hline \multirow{2}{*}{ Variable } & \multirow{2}{*}{$\mathrm{N}$} & \multicolumn{2}{|l|}{ Nilai Teori } & \multicolumn{2}{l|}{ Nilai Sebenarnya } \\
\cline { 3 - 6 } & & Minimum & Maksimum & Minimum & Maksimum \\
\hline $\begin{array}{l}\text { Sistem Pengukuran } \\
\text { Kinerja }\end{array}$ & 163 & 1 & 7 & 3 & 7 \\
\hline Kejelasan Peran & 163 & 1 & 7 & 2 & 7 \\
\hline Kinerja Karyawan & 163 & 1 & 7 & 4 & 7 \\
\hline
\end{tabular}

\subsection{Analisis Faktor}

Analisis faktor bertujuan mendefinisikan struktur suatu data matrik dan mengalaisis struktur korelasi antar sejumlah variabel dengan cara mendefinisikan dimensi atau faktor.

\section{Sistem Pengukuran Kinerja (SPK)}

Analisis faktor sistem pengukuran kinerja dapat dilihat pada Tabel Component Matrix SPK (dalam lampiran). Analisis faktor sistem pengukuran kinerja dapat dilihat pada Tabel Component Matrix SPK (dalam lampiran). Dengan melihat component matrix dan rotated component matrix maka pengelompokan pada variable SPK masing- masing loading factor diatas 0,7. Yaitu antara 0,769 sampai dengan 0,872.

\section{Kejelasan peran}

Pengujian menunjukkan component matrix kejelasan peran terjadi pengelompokan 2 dimensi. Sesuai dengan Hall (2008) dimensi tersebut penulis namakan goal clarity dan 
process clarity. Hasil uji EFA yang penulis lakukan bahwa elemen goal clarity dan role clarity sama dengan Hall (2008) yaitu pertanyaan 1 - 5 mengelompok ke dalam goal clarity sedangkan pertanyaan 6 - 10 mengelompok ke dalam process clarity. Akan tetapi pada pertanyaan 5 nilai loading factornya 0,564 pada dimensi 1 dan 0,525 pada dimensi 2 . Berdasarkan persyaratan acceptable nilai validiti 0,7 atau 0,6 maka pertanyaan no 5 harus dihilangkan dari model (lihat tabel), kemudian dilakukan pemecahan atas model kejelasan peran ini menjadi goal clarity (GC) untuk pertanyaan 1 - 4 dan menjadi process clarity (PC) untuk pertanyaan $6-10$.

Hasil di atas menunjukkan bahwa kejelasan tujuan akan meningkatkan kejelasan peran dimana nilainya di atas 0,7 . Dan kejelasan proses akan membuat seorang karyawan menyediakan waktunya untuk menjalankan tugas-tugasnya juga menetapkan prosedur untuk setiap pekerjaan secara tepat.

\section{Kinerja Karyawan}

Untuk variabel kinerja karyawan (Lampiran Tabel Component matrix kinerja karyawan) menunjukkan component matrix kinerja karyawan.

Berdasarkan pengelompokan uji hasil statistik ditemukan bahwa variable kinerja karyawan memiliki nilai loading factor-nya rata-rata diatas 0,8 hal ini sesuai dengan persyaratan acceptable nilai validiti 0,7 atau 0,6. Sehingga dapat dikatakan variabel kinerja karyawan memiliki nilai validiti yang baik.

\subsection{Analisis Data}

\section{Measurement Model}

\section{Uji Reliabilitas}

Pemeriksaan reliabilitas konstruk dengan melihat output composite reliability dan cronbach's alpha lebih dari 0,7. Hulland, (1999) mengatakan bahwa cronbach's alpha yang nilainya lebih dari 0,7 menunjukkan tingkat yang reliabel.

Tabel 4.3

Quality Criteria (Composite Reliability, Cronbachs Alpha)

\begin{tabular}{|l|l|l|l|}
\hline & AVE & Composite Reliability & Cronbachs Alpha \\
\hline SPK & 0,660 & 0,946 & 0,935 \\
\hline GC & 0,777 & 0,933 & 0,904 \\
\hline PC & 0,683 & 0,915 & 0,884 \\
\hline KK & 0,706 & 0,944 & 0,931 \\
\hline
\end{tabular}




\section{Uji Validitas}

\section{Nilai average variance extracted (AVE)}

Dalam convergen validity dapat dilihat output AVE sangat baik karena kriteria nilai convergen validity dikatakan baik jika memiliki nilai AVE lebih dari 0,50. Hal ini dapat diartikan bahwa seluruh konstruk yang di uji memiliki nilai convergent baik.

\section{Validitas Diskriminan}

\section{Nilai cross loadings}

Kriteria cross loadings adalah masing-masing konstruk haruslah berkorelasi lebih tinggi dibandingkan dengan konstruk yang lainnya.

\section{Tabel 4.4}

\section{Cross Loadings}

\begin{tabular}{|l|l|l|l|l|}
\hline & SPK & Goal Clarity & Process Clarity & Kinerja Karyawan \\
\hline SPK1 & $\mathbf{0 , 8 2 3}$ & 0,552 & 0,421 & 0,487 \\
\hline SPK2 & $\mathbf{0 , 7 9 0}$ & 0,462 & 0,432 & 0,398 \\
\hline SPK3 & $\mathbf{0 , 8 3 3}$ & 0,515 & 0,441 & 0,469 \\
\hline SPK4 & $\mathbf{0 , 8 6 9}$ & 0,454 & 0,502 & 0,483 \\
\hline SPK5 & $\mathbf{0 , 7 7 9}$ & 0,444 & 0,445 & 0,462 \\
\hline SPK6 & $\mathbf{0 , 7 9 8}$ & 0,429 & 0,508 & 0,469 \\
\hline SPK7 & $\mathbf{0 , 8 1 6}$ & 0,384 & 0,491 & 0,451 \\
\hline SPK8 & $\mathbf{0 , 8 2 6}$ & 0,456 & 0,501 & 0,526 \\
\hline SPK9 & $\mathbf{0 , 7 7 1}$ & 0,369 & 0,488 & 0,498 \\
\hline GC1 & 0,513 & $\mathbf{0 , 8 6 3}$ & 0,560 & 0,619 \\
\hline GC2 & 0,509 & $\mathbf{0 , 9 4 2}$ & 0,598 & 0,632 \\
\hline GC3 & 0,453 & $\mathbf{0 , 8 5 2}$ & 0,502 & 0,479 \\
\hline GC4 & 0,485 & $\mathbf{0 , 8 6 6}$ & 0,612 & 0,579 \\
\hline PC6 & 0,519 & 0,582 & $\mathbf{0 , 8 7 6}$ & 0,627 \\
\hline PC7 & 0,455 & 0,520 & $\mathbf{0 , 8 2 2}$ & 0,657 \\
\hline PC8 & 0,447 & 0,479 & $\mathbf{0 , 8 2 8}$ & 0,565 \\
\hline PC9 & 0,409 & 0,581 & $\mathbf{0 , 8 0 4}$ & 0,571 \\
\hline PC10 & 0,548 & 0,509 & $\mathbf{0 , 8 0 1}$ & 0,617 \\
\hline KK1 & 0,498 & 0,641 & 0,599 & $\mathbf{0 , 8 5 2}$ \\
\hline KK2 & 0,468 & 0,664 & 0,577 & $\mathbf{0 , 8 5 9}$ \\
\hline KK3 & 0,502 & 0,572 & 0,658 & $\mathbf{0 , 8 7 6}$ \\
\hline KK4 & 0,493 & 0,564 & 0,642 & $\mathbf{0 , 8 4 5}$ \\
\hline KK5 & 0,452 & 0,503 & 0,568 & $\mathbf{0 , 8 0 9}$ \\
\hline KK6 & 0,479 & 0,427 & 0,658 & $\mathbf{0 , 8 1 1}$ \\
\hline KK7 & 0,527 & 0,498 & 0,632 & $\mathbf{0 , 8 2 9}$ \\
\hline & & & & \\
\hline
\end{tabular}




\section{Perbandingan nilai kuadrat korelasi}

Pengujian metode Fornell-Larcker dilakukan dengan membandingkan square roots atas AVE dengan korelasi vertical laten.

Tabel 4.5

Latent Variable Correlations

\begin{tabular}{|l|l|l|l|l|}
\hline & SPK & GC & PC & KK \\
\hline SPK & $\mathbf{0 , 8 1 2}$ & & & \\
\hline GC & 0,558 & $\mathbf{0 , 8 8 1}$ & & \\
\hline PC & 0,579 & 0,646 & $\mathbf{0 , 8 2 7}$ & \\
\hline KK & 0,582 & 0,660 & 0,737 & $\mathbf{0 , 8 4 0}$ \\
\hline
\end{tabular}

\section{Pengukuran Model / Measurement Structural Model}

Teknik yang akan digunakan dalam penelitian ini path coefficient diperoleh hasil pada gambar berikut:

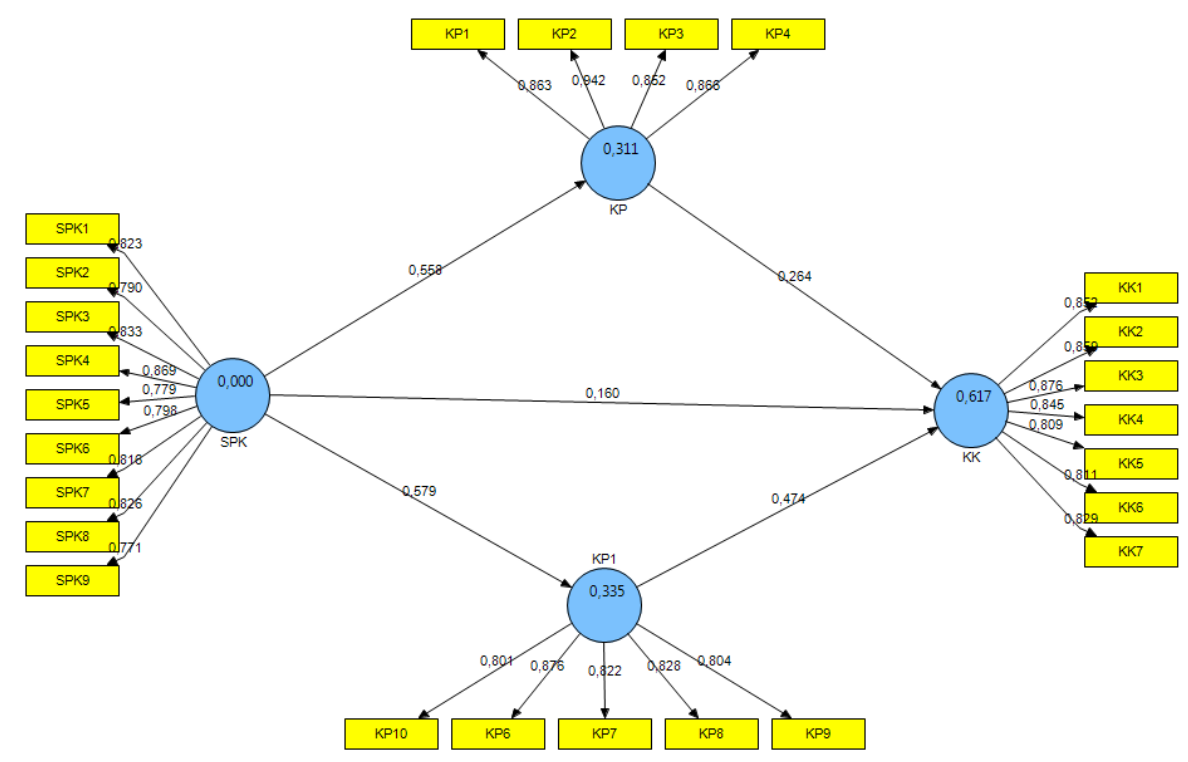

Gambar 4.1:

Full Model Structural Partial Least Square (setelah eliminasi indikator)

Gambar di atas menjelaskan hubungan setiap konstruk dari masing-masing variabel dijelaskan oleh masing-masing indikator. Berdasarkan penelitian Hall 2008, indikator kejelasan peran dipecah menjadi goal clarity dan process clarity 


\section{Coefficient of determination $\left(\mathbf{R}^{2}\right)$}

Kriteria nilai coefficient of determination $\left(\mathrm{R}^{2}\right)$ dikatakan baik jika memiliki nilai $\mathrm{R}^{2}$ lebih dari 0,1 dan berdasarkan persyaratan tersebut, dapat dilihat di tabel 4.6 bahwa coefficient of determination dalam penelitian ini dapat diterima.

\section{Path Coefficient ( $\beta)$}

Pengujian Path Coefficient (koefisien jalur) dilakukan untuk meyakinkan dan melihat kekuatan hubungan antar variabel adalah kuat. Pengujian yang dilakukan dengan menggunakan prosedur bootstrapping dengan 500 kali penggantian.

Tabel 4.6

\section{Pengukuran Struktural Model}

\begin{tabular}{|l|l|l|l|l|}
\hline \multirow{2}{*}{ Variabel Dependen } & \multicolumn{2}{|l|}{ Variabel Independen } & \multirow{2}{*}{$\mathrm{R}^{2}$} \\
\cline { 2 - 4 } & SPK & GC & PC & \\
\hline GC & $\begin{array}{l}0.558 \\
(10.073)^{* * *}\end{array}$ & & & 0.311 \\
\hline PC & $\begin{array}{l}0.579 \\
(8.574)^{* * *}\end{array}$ & & & 0.335 \\
\hline KK & $\begin{array}{l}0.160 \\
(2.170)^{* *}\end{array}$ & $\begin{array}{l}0.264 \\
(3.652)^{* * *}\end{array}$ & $\begin{array}{l}0.474 \\
(5.471)^{* * *}\end{array}$ & 0.617 \\
\hline
\end{tabular}

Keterangan:

*** Signifikan pada $1 \%$

** Signifikan pada $5 \%$

\subsection{Pengujian Hipotesis}

\section{Hipotesis 1}

Berdasarkan tabel 4.6 sistem pengukuran kinerja memiliki hubungan positif dengan goal clarity yaitu $(\beta=0,558, \mathrm{t}=10,073, \mathrm{p}<0,01)$, dan sistem pengukuran kinerja memiliki hubungan positif dengan process clarity yaitu $(\beta=0,579, \mathrm{t}=8,574, \mathrm{p}<0,01)$, maka berdasarkan tabel menunjukkan bahwa Nilai t-statistic tersebut berada jauh di atas nilai kritis $\pm 2,576$, jika sistem pengukuran kinerja meningkat maka kejelasan peran akan mengalami peningkatan. Kesimpulannya Hipotesis 1 diterima. 


\section{Hipotesis 2}

Tabel 4.6 menunjukkan bahwa kinerja karyawan berpengaruh positif terhadap goal clarity $(\beta=0,264, \mathrm{t}=3,652, \mathrm{p}<0.01)$, dan kinerja karyawan memiliki hubungan positif dengan process clarity $(\beta=0,474, \mathrm{t}=5,471, \mathrm{p}<0,01)$, karena nilai $\mathrm{t}$-statistic tersebut berada jauh diatas nilai kritis 2,576. Sehingga Hipotesis 2 diterima.

\section{Hipotesis 3}

Berdasarkan hasil hipotesis, terlihat ada hubungan positif antara variabel pengukuran kinerja dan kinerja karyawan $(\beta=0,160, t=2,170, p<0,05)$, tabel 4.7 menunjukkan bahwa Nilai t-statistic tersebut berada jauh di atas nilai kritis 1.960, berarti jika sistem pengukuran kinerja meningkat maka kinerja karyawan akan mengalami peningkatan. Kesimpulannya Hipotesis 3 diterima.

\subsection{Pembahasan}

\section{Pembahasan Hasil Hipotesis 1}

Melalui analisis faktor, penelitian ini berhasil menunjukan bahwa peningkatan sistem pengukuran kinerja maka kejelasan peran akan mengalami peningkatan. Menurut Marginson, McAulay and Roush (2011), kontribusi yang menunjukkan sifat dan tingkat efek psikologis yang positif dihasilkan oleh ukuran kinerja. Sistem pengukuran kinerja bisa meningkatkan persepsi karyawan atas setiap dimensi dalam kejelasan peran.

\section{Pembahasan Hasil Hipotesis 2}

Pada hipotesis 2 ini, variabel goal clarity dan process clarity berpengaruh positif terhadap kinerja karyawan. Hasil Hipotesis ini sejalan dengan penelitian yang dilakukan oleh Hall (2008), bahwa kejelasan peran berkaitan dengan perilaku yang meningkatkan kinerja karyawan yang berhubungan dengan perilaku psikologis seseorang. Penelitian ini mendukung penelitian terkini yang menguji hubungan antara kejelasan peran secara keseluruhan dan kinerja sebuah pekerjaan memperoleh bukti empiris bahwa tingkat kejelasan peran yang lebih tinggi akan meningkatkan kinerja sebuah pekerjaan yang kemudian akan timbul perasaan positif terhadap pekerjaan tersebut (Spreitzer, 1995). 


\section{Pembahasan Hasil Hipotesis 3}

Hasil penelitian menunjukan bahwa sistem pengukuran kinerja dapat memberikan informasi yang relevan terhadap karyawan untuk bekerja karena informasi kinerja membuat para karyawan lebih memahami tentang keadaan lingkungan, sehingga menghasilkan sebuah alternatif yang lebih baik dengan rangkaian tindakan efektif dan efisien dan berdampak pada peningkatan kinerja karyawan. Dan informasi kinerja yang komprehensif dari sistem pengukuran kinerja memberikan informasi yang lebih spesifik dan relevan sehingga dapat meningkatkan kinerja karyawan.

Tabel 4.7

Hasil Temuan Hipotesis

\begin{tabular}{|l|l|l|}
\hline Hipotesis & Keterangan & Temuan \\
\hline H1 & $\begin{array}{l}\text { Terdapat hubungan positif antara sistem } \\
\text { pengukuran kinerja dan kejelasan peran }\end{array}$ & Didukung \\
\hline H2 & $\begin{array}{l}\text { Terdapat hubungan positif antara kejelasan peran } \\
\text { dan kinerja karyawan }\end{array}$ & Didukung \\
\hline H3 & $\begin{array}{l}\text { Terdapat hubungan positif antara sistem } \\
\text { pengukuran kinerja dan kinerja karyawan }\end{array}$ & Didukung \\
\hline
\end{tabular}

Hasil Hipotesis diatas sejalan dengan penelitian yang dilakukan oleh (Kaplan dan Norton 1996, Epstein dan Manzoni 1998, Atkinson dan Epstein 2000), sistem pengukuran kinerja ini dapat meningkatkan kinerja, hal ini dicapai dengan memfokuskan upaya pada tujuan pencapaian, perhatian berkonsentrasi pada proses kritis, pengorbanan untuk memastikan keputusan optimal, dan membantu manajer belajar tentang strategi dan kinerja.

\subsection{Uji Jalur}

Pengaruh goal clarity terhadap kinerja karyawan menunjukkan nilai koefisien jalur adalah 0,264. Nilai t diperoleh sebesar 3,652 lebih besar dari nilai t tabel yakni sebesar 2,606. Dapat dikatakan bahwa hasil ini menunjukkan bahwa goal clarity sangat kuat pengaruhnya terhadap kinerja karyawan. Pengaruh process clarity terhadap kinerja karyawan menunjukkan nilai koefisien jalur sebesar 0,474. Nilai t diperoleh sebesar 5,471. Seperti kita ketahui sebelumnya bahwa nilai t tabel sebesar 2,606 berarti lebih kecil dari t hitung atau dapat dikatakan bahwa process clarity berpengaruh kuat terhadap kinerja karyawan. 
Uji jalur (path analysis) dihitung dengan menggunakan The Sobel's test. Hasil perhitungan the Sobel's test menunjukkan nilai 23,863. Maka dapat dikatakan bahwa sistem pengukuran kinerja dapat meningkatkan kinerja karyawan melalui kejelasan peran (goal clarity dan process clarity).

\section{SIMPULAN DAN SARAN}

\subsection{Simpulan}

Berdasarkan hasil dari pengujian dengan menggunakan partial least square (PLS) diketahui bahwa SPK berpengaruh langsung terhadap kinerja karyawan dan tidak langsung melalui kejelasan peran. Selain itu untuk melihat bagaimana pengaruh tidak langsung kejelasan peran terhadap hubungan SPK dan kinerja karyawan, penulis melakukan uji jalur. Berdasarkan uji jalur menggunakan sobel's test ditemukan bahwa hubungan SPK dan kinerja karyawan adalah dipengaruhi oleh faktor mediasi kejelasan peran.

\subsection{Keterbatasan Penelitian}

Penelitian ini dilakukan di perusahaan jasa, oleh karena itu generalisasi hasil penelitian ini, misalnya diperusahaan manufaktur, harus dilakukan secara hati-hati karena beberapa peneliti sebelumnya telah menyebutkan bahwa perusahaan jasa dan manufaktur memiliki karakteristik yang berbeda (Auzair \& Langfield-Smith, 2005; Winata \& Mia, 2005). Selain itu responden penelitian ini adalah level karyawan akan tetapi dari hasil yang diterima penulis masih ada responden pada level manajer.

\subsection{Saran}

Penelitian berikutnya dapat dilakukan dengan melakukan studi yang lebih luas terhadap perusahaan yang terdaftar di BEI atau dengan melakukan perbandingan kerangka penelitian ini antara perusahaan jasa dan manufaktur. Penelitian berikutnya dapat melakukan perbandingan responden level karyawan dan level manajer

\subsection{Implikasi}

Dengan bukti empiris diatas diharapkan dapat membawa implikasi terhadap perusahaan jasa khususnya perbankan di Lampung, Palembang, Jambi dan Bengkulu bahwa dengan kejelasan peran karyawan tahu apa yang harus dilakukan. Dan bagi perusahaan jasa diharapkan dapat mensosialisasikan atau membuat SOP terhadap karyawan atas pekerjaan yang harus dilakukan. 


\section{DAFTAR PUSTAKA}

Abramis, D. J. (1994) Work role ambiguity, job satisfaction, and job performance: metaanalyses and review. Psycological Reports, 75, 1411 - 1433

Al-Gahtani, S. S., Hubona, G. S., \& Wang, J. 2007. Information technology (IT) in Saudi Arabia: Culture and the acceptance and use of IT. Information \& Management, 44(8): 681-691.

Auzair, S. M., and K. Langfield-Smith. 2005. The effect of service process type, business strategy and life cycle stage on bureaucratic MCS in service organizations. Management Accounting Research 16 (4):399-421.

Baines, A., and K. Langfield-Smith. 2003. Antecedents to management accounting change: a structural equation approach. Accounting, Organizations and Society 28 (7-8):675698

Binnewies, C., S. Ohly, and C. Niessen. 2008. Age and creativity at work. Journal of Managerial Psychology 23 (4):438-457.

Bititci, Umit S., Allan S. Carrie and Liam McDevitt, Integrated performance measurement systems: a development guide. University of Strathclyde, Glasgow, UK. International Journal of Operations \& Production Management, Vol. 17 No. 5, 1997, pp. 522-534.

Burney, L. L., Henle, C. A., \& Widener, S. K. 2009. A path model examining the relations among strategic performance measurement system characteristics, organizational justice, and extra- and in-role performance. Accounting, Organizations and Society, 34(3-4): 305-321.

Camison, C., \& Lopez, (2010). "An examination of the relationship between manufacturing, flexibility and firm performance: The mediating role of innovation." International Journal of Operations \& Production Management, 30 (8) : 853 - 878

Chenhall, R. H. 2003. Management control systems design within its organizational context: findings from contingency-based research and directions for the future. Accounting, Organizations and Society 28 (2-3):127-168.

- 2005. Integrative strategic performance measurement systems, strategic alignment of manufacturing, learning and strategic outcomes: an exploratory study. Accounting, Organizations and Society 30 (5):395-422.

Collier, P., and A. Gregory. 1995a. Investment appraisal in service industries: a field study analysis of the U.K. hotels sector. Management Accounting Research 6 (1):33-57.

1995b. Strategic management accounting: a UK hotel sector case study. International Journal of Contemporary Hospitality Management 7:16-21. 
Falk, R. Frank \& Nancy B. Miller. 1992. A primer for soft modeling. Akron: University of Akron

Fornell, C., \& Bookstein, F. 1982. Two structural equation models: LISREL and PLS applied to consumer exit-voice theory. Journal of Marketing Research, 19: 440-452.

Gomes, C. F. 2010. Assessing operational effectiveness in healthcare organizations: a systematic approach. International journal of health care quality assurance 23 (2):127.

Goodale, J. C., D. F. Kuratko, and J. S. Hornsby. 2008. Influence factors for operational control and compensation in professional service firms. Journal of Operations Management 26 (5):669-688.

Hall, M. 2008. The effect of comprehensive performance measurement systems on role clarity, psychological empowerment and managerial performance. Accounting, Organizations and Society, 33(2-3): 141-163.

Hulland, J. 1999. Use of partial least squares (PLS) in strategic management research: a review of four recent studies. Strategic Management Journal, 20(2): 195-204.

Jackson, S. E., \& Schuler R. S. (1985) A meta analysis and conceptual critique of research on role ambiguity and role conflict in work setting. Organizational Behavior and Human Decision Processes, 36, 16 - 78.

Kaplan, R. S., and D. P. Norton. 1996. The Balanced Scorecard: Translating Strategy into Action Boston, MA: Harvard Business School Press.

Kihn, L.-A. 2010. Performance outcomes in empirical management accounting research: Recent developments and implications for future research. International Journal of Productivity and Performance Management 59 (5):468-492.

Lawler, E. E. (1992) The ultimate advantage: creating the high involvement organization. San Francisco: Jossey-Bass

McClelland, D. C., Personality (New York: Holt, Rinehart \& Winston, 1967).

Robbins, Stephen., P., Timothy A Judge. 2007., Perilaku Organisasi, Salemba Empat, Jakarta

Sawyer, J.E. (1992) Goal and process clarity: specification of multiple constructs of role ambiguity and a structural equation model of their antecedents and consequences. Journal of Applied Psycology, 77 : 130 - 142

Shields, M. D. 1997. Research in Management Accounting by North Americans in the 1990s. Journal of Management Accounting Research 9:3-61.

Spohrer, J., and P. P. Maglio. 2008. The Emergence of Service Science: Toward Systematic Service Innovations to Accelerate Co-Creation of Value. Production \& Operations Management 17 (3):238-246.

Spreitzer, G. M. 1995. Psychological empowerment in the workplace: dimensions, measurement, and validation. Academy of Management Journal, 38(5): 1442-1465. 
Kizilos, M. A., \& Nason, S. W. 1997. A dimensional analysis of the relationship between psychological empowerment and effectiveness, satisfaction and strain. Journal of Management, 23(5): 679-704.

Urbach, N., and F. Ahlemann. 2010. Structural equation modeling in information systems research using partial least squares. Journal of information Technology Theory and Application 11 (2):5-39. 